GEOLOGICAL SECTION ALONG MIDDLE RIVER IN CENTRAL IOWA.

J. L. TILTON. 
1

1

1 


\section{GEOLOGICAL SECTION ALONG MIDDLE RIVER IN CENTRAL IOWA.}

BY J. L. TILTON.

The "Three Rivers Country" comprises the greater portion of Warren and Madison counties in central Iowa. It is drained by the streams respectively known as the North, Middle and South rivers, which flow in courses nearly parallel to one another, and empty into the Des Moines river near the northeastern corner of the first named county. Along the median of these water courses the geological section herein described was constructed. It extends from Ford, on the Des Moines, in a slightly south of west direction to Winterset, the county seat of Madison.

Of the geological problems presented by the region, none is of greater practical import than the determination of the thickness of the Lower or productive Coal Measures. Middle river affords especially favorable opportunities for solving the problem. The stream now flows in a direction approximately normal to the old Carboniferous shore line. The section connects the Ford bluff outerops, whose relations to the Lower Carboniferous limestones have been definitely determined, and the Winterset exposure which has been regarded as a typical development of the base of the Upper Coal Measures in Iowa. In its general 
features it also serves as a check on a similarly constructed section parallel to it but some twenty miles to the north. It further answers as a base to which all detailed stratigraphical work in Warren and Madison counties may be referred. Lastly, one of the principal objects has been to determine the position and extent of folds or undulations in the strata which might serve as guides to intelligent prospecting for natural gas and oil.

If along the line of the general section there is encountered a heavy limestone formation whose outcrop can be readily traced northwestward into Guthrie county and southward into Missouri, connecting with a very similar limestone which has been recognized near the northern boundary of that state, a clear and natural line of demarkation is obtained for separating the Iowa Coal Measure area into two distinct districts, one, made up mostly of shore and swamp deposits, in which coal was abundantly formed (Des Moines terrane), and the other composed chiefly of more strictly maritime beds (Missouri terrane). This is the first important limestone above those of the great Carboniferous basement.

A knowledge of the position of this off-shore line has an important theoretical and practical bearing. Theoretically it tells of the physical conditions under which a part of the Iowa land surface was formed and the relations of sea and land during Carboniferous times; practically, it gives an exact and rational division between the Lower and Upper Coal Measures, above which conditions favorable to the formation of thick coal seams cease to exist. Also, new data are furnished by which to judge the depth of the Lower Coal Measures with their rich contents.

At the eastern end of the general section the surface is quite rugged on the south, while on the north the 
broad flood plain of the Des Moines stretches out for a distance of several miles. From the mouth of Middle river valley to the west county line of Warren the surface slopes quite gradually on both sides, though the river generally hugs the southern margin of its valley, thus bringing it closer to the high, rolling uplands on the soutl, while to the north the surface rises in more gradual undulations. Near the western boundary of Warren county the hills become more rugged and precipitous. In the eastern part of Madison county, where the limestone deposits of the Upper Coal Measure strata begin, the valley is contracted to a gorge, the high limestone bluffs rising quite abruptly on either side of the. river to a height of fully two hundred feet.

The first outerop to be considered is one mile east of Ford ( $\mathrm{Tp} .77 \mathrm{~N}$., R. XXII W., Sec. 10). It is as follows (number 1 in figure 2 ):
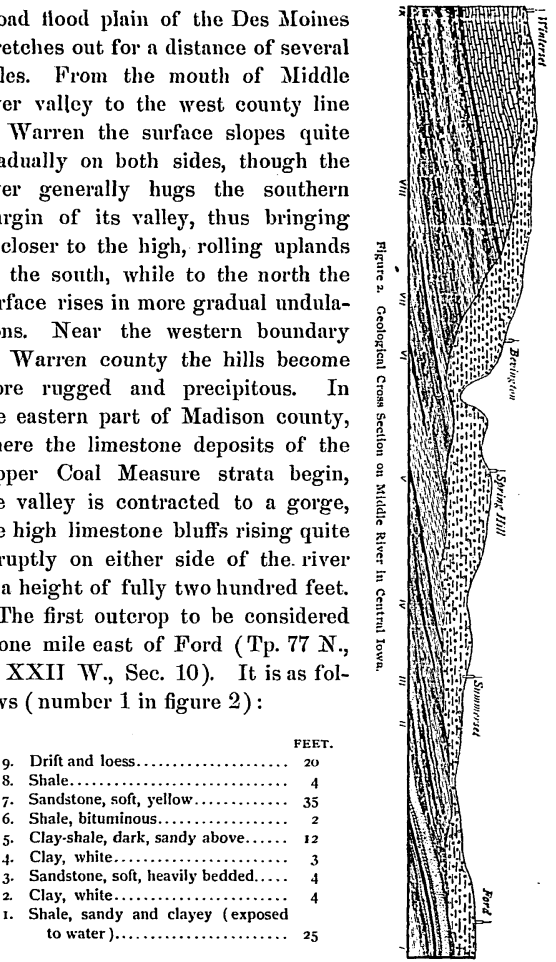
The section is located at the crest of a low anticline. From this place to a point a mile west of Ford the strata can be traced in the bluff which forms the sonth bank of the Des Moines and Middle rivers. Beyond this point the exposures are not so continuous, but there seems to be little room for doubt that the principal seam of coal, which appears just above the railroad track at the station, thins out somewhat before it reaches the water level of Middle river about one-fourth of a mile east of the bridge at Clarkson. At this point the upper part of the vein is well exposed. The overlying sandstone is present, but is not so thick as at Ford, and the dark shale and soft sandstone crop out in the bluff. At this place another vein begins that may be traced three miles up the river; the bituminous shales which overlie it being especially noticeable near the bridge on the road to Carlisle. A third seam, a few feet above, appears best developed two miles to the southwest and at Summerset, at both of which places shafts are located. The conl is said to thin out between the two points. Seventy-five feet above the last mentioned seam is another which is mined at Summerset and also a few miles eastward as a surface seam. This is the vein which outcrops in the bluff at Summerset station.

A short distance east of Summerset, at the mouth of a ravine in which are situated the Jones and Benham coal mines (Tp. 77 N., R. XXIII W., Sec. 22, NE. qr., SE. $\frac{1}{4}$ ) the outerop shows (number 2 ):

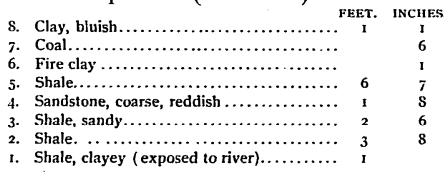


The sandstone above the seam of coal is a continuation of that which is so prominent in the clift at Ford. It disappears beneath the bed of the river just west of Summerset. The coal seam overlying the sandstone in the bluff at Summerset outcrops repeatedly in the hillsides for a distance of several miles to the east where it is "drifted." It thins out rapidly west of the town. The Summerset section (Tp. 77 N., R. XXIII W., Sec. 31, NE. qr.) is as follows (number 3 ):

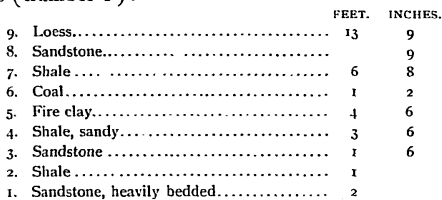

From Summerset to Spring Hill, the outcrops in the immediate vicinity of the river are not very numerous. Several thin veins of coal are found, the best natural exposure occurring about half way between the towns mentioned. A little to the south of the river the seams supply a limited quantity of coal for local consumption. The most instructive section is a short distance west of the first-named town (Tp. 76 N., R. XXIV W., Sec. 2, NW. qr., SE. $\frac{1}{4}$ ), where is exposed (number 4 ):

FEET. INCHES.

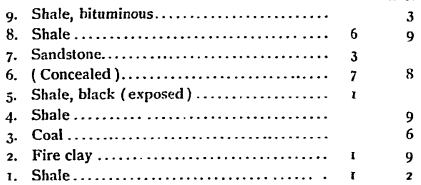


Immediately west of Spring Hill an excellent section has been disclosed in opening a seam of coal. Northward in the ravines sloping into North river valley, and in a blufl' by the stream itself, are exposures revealing shale and sandstone both above and below a narrow pocket of coal, whose main axis is directed north and south, the stratum thinning out very rapidly east and west.

A mile and a quarter west of the town (Tp. $76 \mathrm{~N}$., R. XXV W., Sec. 12, NE. qr., SW. $\frac{1}{4}$ ) is the following section (number 5 ):

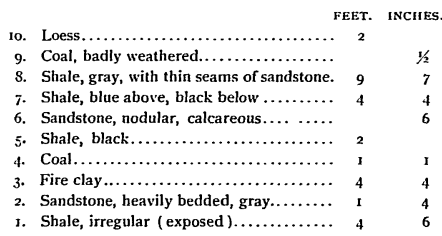

Between Lothrop and Bevington, an interval of three miles, few outcrops occur. 'The scarcity of exposures and the general relations of the strata argue for the absence of any layer that by resisting weathering would protude through the overlying loess or become exposed in the ravines. This, together with the fact that the lowermost stratum found above is argillaceous shale and the uppermost found below is a sandstone passing in places into a sandy shale, give evidence that the strata thus concealed are largely shales.

Two miles west of Greenbush is a section in a ravine where coal is at present obtained by "stripping" (Tp. 76 N., R. XXV W., Sec. 1, NW. qr., NE. $\frac{1}{4}$ ). The upper 
half of the section is obtained about fifty yards west of the point where the lower half is found (number 6 ):

\begin{tabular}{|c|c|c|c|}
\hline & Sandstone, shaly. & FEET. & INCHES \\
\hline II. & 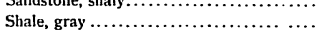 & $\begin{array}{l}2 \\
\mathbf{I}\end{array}$ & $\begin{array}{l}2 \\
3\end{array}$ \\
\hline . & Shale, reddish $: \ldots \ldots \ldots \ldots \ldots \ldots \ldots \ldots \ldots$ & 2 & 3 \\
\hline 9. & Sandstone, gray, shaly ................. & & 5 \\
\hline S. & Shale, blue $\ldots \ldots \ldots \ldots \ldots \ldots \ldots \ldots \ldots \ldots \ldots \ldots \ldots$ & & 9 \\
\hline 7. & Sandstone, fossiliferous.................. & I & 3 \\
\hline & Shale, blue (exposed) $\ldots \ldots \ldots \ldots \ldots \ldots \ldots$ & & 7 \\
\hline 5 . & Shale $\ldots \ldots \ldots \ldots \ldots \ldots \ldots \ldots \ldots \ldots \ldots \ldots \ldots \ldots \ldots$ & 4 & \\
\hline 4. & Limestone, arenaceous, fossiliferous ........ & & 6 \\
\hline 3 . & Shale, black.......................... & & 7 \\
\hline 4 & 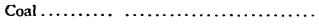 & & 6 \\
\hline & Fire clay (exposed) $\ldots \ldots \ldots$ & & 4 \\
\hline
\end{tabular}

A short distance southwest of Bevington, in the ravines and in the bluf' near the river ( $T_{p} .76 \mathrm{~N}$., R. XXVI W., Sec. 36, SW. qr., NW. $\frac{1}{4}$ ) one of the best exposures (number 7 ) shows:

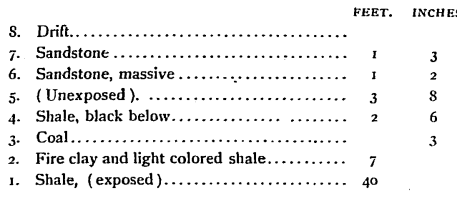

Between Bevington and Patterson heavy sandstones are quite prominent, shale lying both above and below. But one coal horizon is exposed.

The massive sandstones which lie near the railroad track from one to two miles west of Patterson are undoubtedly represented a mile and a half southwest by a corresponding stratum a few feet above the water. Large blocks of a heavily bedded sandstone were found on the hillside at a level where such a stratum should be, but no exposure 
of undisturbed layers appeared. Above this stratum shale is exposed though not to its full extent.

Two miles southwest of Patterson ( $\mathrm{T}_{\mathrm{p} .} \mathbf{7 6} \mathrm{N}$., R. XXVII W., Sec. 35, SW. qr. NE. $\frac{1}{4}$ ) there is a good exposure (number 8 ) in the bluffs bordering the river on the south :

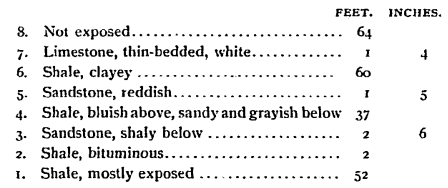

From the Jast section, southwest of Patterson, to Winterset the limestone (Upper Coal formation ) capping the hills has so protected the underlying softer strata from erosion that the bluffs rise high and steep in the immediate vicinity of the river. There are three rock layers of special prominence: the first a sandstone fifty-two feet above the river at Patterson, the second a sandstone thirtyeight feet above the first, the third, the limestone cliff, sixty to ninety feet above the last. Even where there are no good exposures, these strata have so resisted erosion that the sides of the hills south of the river are terraced. These characteristic ledges with their associated strata are perhaps best shown across the river from Tileville. The only good indications of coal immediately underlying the lowest stratum of limestone disappear beneath the river bed a mile east of Buffalo bridge.

West of the locality last mentioned the highlands approach very near the river, which has formed a gorge perhaps half a mile wide. The upper portion of the section (Tp. 75 N., R. XXVII W., Sec. 6, NW. qr.) is easily 
traced in the upper part of the ravine along the road sonth of Winterset; the lower half is exposed in this and other ravines near the river, but the lowest stratum of limestone outerops in the bed of the river a mile to the east. The observations made here correspond essentially with those made by White, whose section (number 9) is here given :

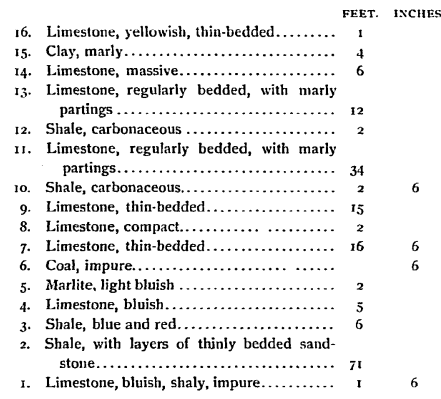

The Upper Coal Measures form an almost continuous limestone formation that may be readily distinguished from the clay and sandy formations occurring eastward. On the north bank of Middle river the Upper Coal Measure strata extend along the highlands between Cedar creek and Middle river from Winterset to just east of Tileville. At. Winterset they form a stratum 110 feet thick, the base of the formation resting seventy-two feet above the river bed. At Tileville the capping limestone is about seventy feet thick; the base 128 feet above the river bed.

10 G. Rep. 
In conclusion it may be said that the section clearly agrees with the Raccoon river section twenty miles farther north, and in the same general direction. A further agreement is manifest in a very marked absence of folds or undulations in the layers, the only one of importance being the Ford anticline, at the extreme eastern end of the section, which was made out some years ago. The third important consideration is that the shales and sandstones continue, to the exclusion of calcareous beds, from the Lower Carboniferous basement up to the very base of the great limestone of Winterset where they abruptly stop. A sharp line of demarkation is thus recognized between the coal bearing strata and the formations where fuel-furnishing layers are practically absent. 